Bonilla, L. C. (2020). Historia y narraciones artísticas sobre nuestra señora de Ujarrás.

Revista Herencia 33 (2), julio-diciembre, 7-30.

\title{
HISTORIA Y NARRACIONES ARTÍSTICAS SOBRE NUESTRA SEÑORA DE UJARRÁS
}

History and Artistic Stories about Our Lady of Ujarrás

\author{
Luis Carlos Bonilla Soto \\ Universidad Estatal a Distancia, Costa Rica \\ Icbonillasoto@gmail.com
}

Recibido: 10-03-2010

Aprobado: 29-05-2020

\begin{abstract}
Luis Carlos Bonilla Soto es licenciado en Sociología por la Universidad de Costa Rica. Investigador en los campos del Arte Sacro y de la Piedad Popular en la Curia Metropolitana de San José. Docente en la Universidad Estatal a Distancia.
\end{abstract}

\section{RESUMEN}

El arte sacro narra historias sobre las creencias de los pueblos y sobre la historia de los seres humanos alrededor del mundo. En Costa Rica, Nuestra Señora de Ujarrás ha sido venerada desde 1565. Primero en el Valle de Ujarrás y luego en Paraíso de Cartago. Esta advocación de Santa María Virgen ha sido representada mediante distintas formas en las artes, tales como esculturas, vitrales, pinturas de caballete y murales. De este modo, esta investigación presenta las obras de arte más importantes que se vinculan a su culto.

Palabras clave: arte; devoción; Costa Rica; Virgen María; Ujarrás

\begin{abstract}
Sacred art tells stories about people's beliefs and the history of human beings around the world. In Costa Rica, Our Lady of Ujarrás has been venerated since 1565. First in Ujarrás Valley and then in Paraíso, Cartago. This title of Saint Mary Virgin has been represented by different forms of arts, such as sculptures, stained glass, paintings and murals. In this way, this research shows the most important art linked to its cult.
\end{abstract}

Keywords: art; devotion; Costa Rica; Virgin Mary; Ujarrás 


\section{Introducción: entre la leyenda y el hecho histórico}

La existencia de la efigie de Nuestra Señora de la Pura y Limpia Concepción del Rescate de Ujarrás, conocida también como la Candelaria, es la referencia material que ha sostenido el imaginario y las prácticas de fe católicas en lo que hoy corresponde al cantón de Paraíso en la provincia de Cartago; devoción sumamente restringida a esta zona de Costa Rica, con ligeras difusiones de la misma por las gestiones de sacerdotes y laicos devotos.

En torno a esta imagen se han tejido una serie de narraciones. Unas sostenidas con el respaldo documental y otras desde la transmisión oral en las familias ujarraceñas - paraiseñas. La síntesis escrita de los mitos y milagros originarios, en torno a esta advocación, las realizó primordialmente Eladio Prado Sáenz y han sido reproducidas por distintos medios escritos, contadas con pequeñas variantes entre los lugareños y traducidas a un lenguaje pictórico de mano de distintos artistas, sobre las cuales se puntualizará en las siguientes secciones de este escrito.

En la primera mitad del siglo XX, Prado (1920) describe la historia de la imagen, con un estilo anecdótico y con trazos de realismo mágico, abordando así la forma en que alcanzó fama, en la región cartaginesa, la mediación celestial de la Virgen de Ujarrás.

Si bien han existido momentos en que la divulgación de dicha advocación ha trascendido este espacio geográfico, el fervor está arraigado, de forma casi exclusiva, entre los descendientes de los pobladores del Ujarrás colonial. Por lo cual, el conocimiento de esta representación de Santa María Virgen, es claramente menos difundida que la de Nuestra Señora de los Ángeles, devoción que surge a pocos kilómetros de la primera, un siglo después de la de Ujarrás.

El culto a la imagen de Ujarrás se ha mantenido a lo largo de cinco siglos. Sin embargo, en algunos sectores de creyentes se afirma una supuesta disputa entre su devoción y la tributada a la Virgen de los Ángeles. Tal es el caso del segundo arzobispo de San José, Víctor Manuel Sanabria Martínez, quien afirmó: "Inalterable permaneció la devoción a Nuestra Señora de Ujarrás, hasta que a la devoción de la Virgen Chapetona', se sobrepuso el de la 'Virgen Mulata'..." (Sanabria, 2014, p. 195). Contrario a dicha afirmación, el historiador Manuel Benavides Barquero (2005), ha constado que la aparente disputa no surgió con el hallazgo en la Puebla de los Pardos, pues ambos cultos marianos coexistieron 
y coexisten hasta la fecha, con la única diferencia en el carácter regional del primero y el carácter nacional del segundo.

El hecho material que sostiene el culto de Ujarrás es la imagen primigenia de esta advocación mariana, cuya existencia, trato y soporte económico de su ornamentación, se puede rastrear en documentos históricos a partir de 1593, año de fundación de la primera cofradía de la Inmaculada Concepción en Cartago (Jerez, 2018).

Sobre la manufactura de dicha escultura existen distintas hipótesis, la mayoría generadas a partir de las propuestas de Prado. Se dice que su rostro y manos provienen de España o de Guatemala, que su cuerpo "de gracia" fue esculpido posteriormente, debido a que guarda desproporción y diferencias de calidad con respecto al rostro y manos. Pero, ninguno de dichos planteamientos, ni la manera en que la imagen llegó al Valle en cuestión, han podido ser verificados ni falseados.

La descripción más conocida de la imagen la realizó Prado en 1920. Esta dice:

\footnotetext{
"Tiene la imagen, un mirar grave y reposado, suave y dulce. Ojos grandes y negros y rasgados. Cejas muy arqueadas. Pestañas muy crespas. Boca pequeña; labios muy finos. Mejillas sonrosadas. Los bucles, negros, le caen hasta la mitad de la espalda. Tiene las manos juntas, en actitud de orar y dirige la mirada a quien la invoca, de suerte que, de cualquier parte que se la mire, ve uno sus ojos sobre los de uno mismo, como si estuviera atenta a lo que se diga, como si nos siguiera con su mirar sereno. El cuerpo es, ciertamente defectuoso; no guarda proporción con el rostro. Tiene manto esculpido, sobre el cual se le pone el rico manto de seda y grana que viste por lo regular. Viste calzado." (Prado, 1989, pp. 25-26). ${ }^{1}$
}

La obra primigenia ha sido intervenida en su policromía en distintas ocasiones. Acerca de las realizadas en la época colonial, la investigadora Verónica Jeréz Brenes (2018, p 164), cita documentación del siglo XVIII en la que se evidencia la inversión, por parte de la cofradía, en el arreglo o retoques de imágenes peregrinas entregadas al imaginero Francisco Taboada, y en arreglos al ajuar del altar. Asimismo, en la primera mitad del siglo XX el imaginero Francisco Ramos Pacheco, estuvo en la parroquia de Paraíso retocando la imagen principal2 $^{2}$ (Entrevista a Myriam Quirós Quesada, 2015).

\footnotetext{
${ }^{1}$ Benavides hace otra descripción de la imagen en el Anexo 1 de la publicación La Romería a Ujarrás. Reducto de la identidad cultural de Paraíso (2005, p. 128).

2 Se conservan en manos de familias de Paraíso pequeñas imágenes de la Virgen de Ujarrás talladas en madera por Ramos.
} 
Imagen 1. Colocación del saco rústico con el que, según la tradición local, fue hallada la imagen de la Virgen de Ujarrás. Acción a cargo de la Señora Flory Quesada.

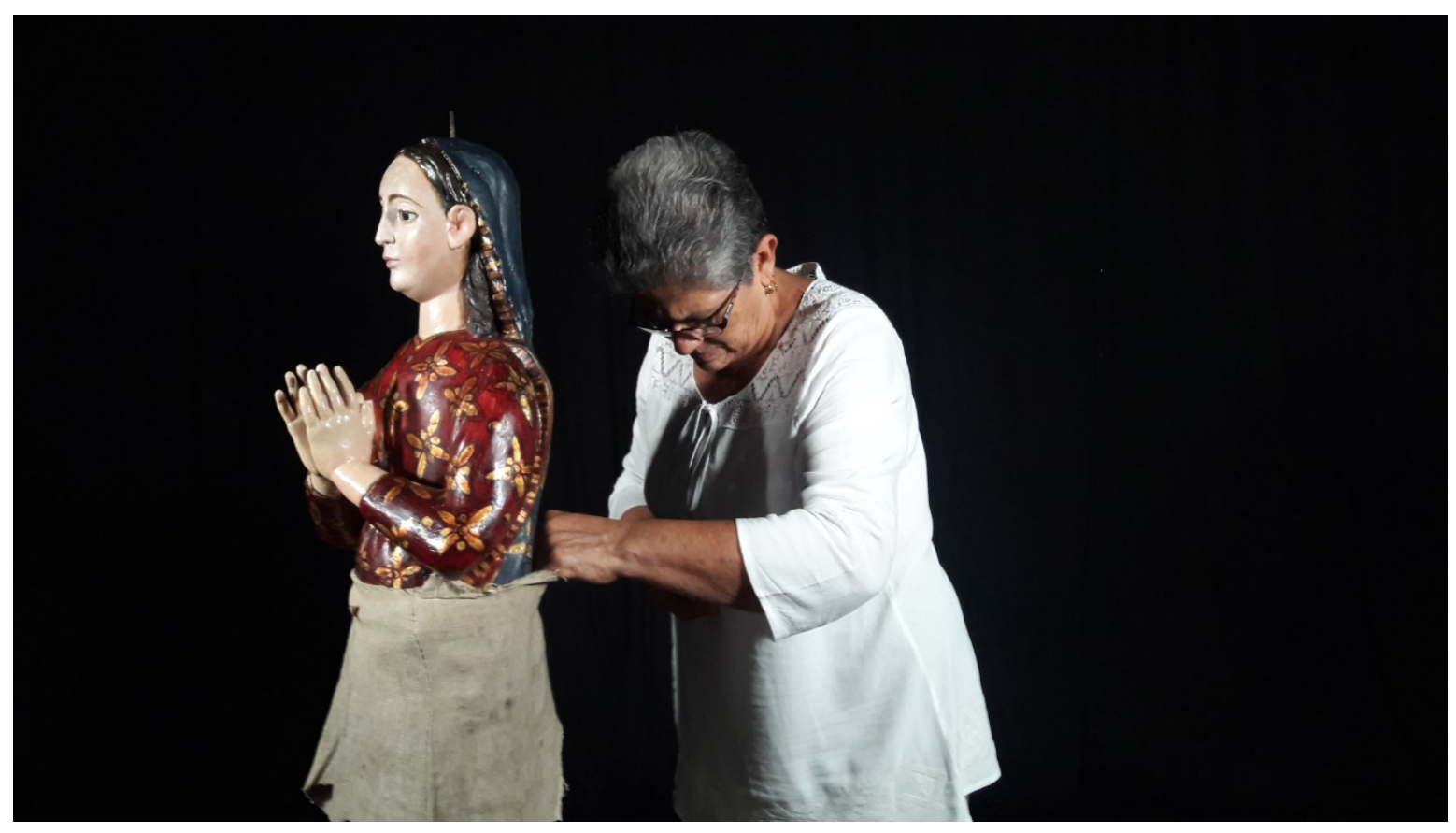

Foto: Luis Carlos Bonilla Soto.

La última restauración fue realizada por la especialista Mercedes Fontana Hernández entre el 2004 y 2005. En la misma se recuperó una de las policromías antiguas en las que la vestimenta se compone de un vestido rojo, manto azul y estilizaciones florales doradas (Cfr. Imagen 1).

Por tradición se le viste, pero no se pude aducir por ello, que la imagen se confeccionó con miras a ser vestida de manera única y estricta, pues si fuera una obra exclusivamente de vestir pudo haber sido articulada a partir de bastones, sin necesidad alguna de cuerpo de bulto (como sí es el caso de la peregrina expuesta en la Imagen 2).

Incluso, en la novena preparatoria a la Fiesta de la Candelaria del año 2005, luego de la restauración realizada por Fontana, la imagen de la patrona de los paraiseños fue colocada en su altar, tal cual, sin vestidos de tela. 
Imagen 2. Imagen peregrina. Comprada por Ana Isabel Monge Valverde al cura de Paraíso y devuelta a su pueblo de origen, como su última voluntad. Actualmente en el Museo Histórico Religioso Nuestra Señora de Ujarrás.

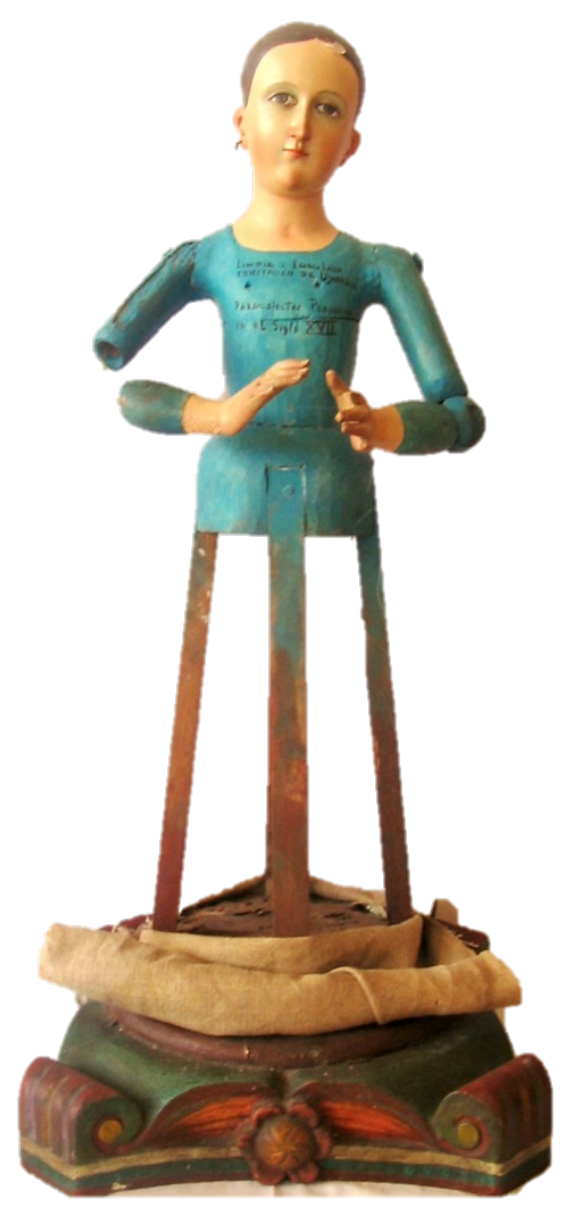

Foto: Luis Carlos Bonilla Soto.

El lenguaje iconográfico de la imagen ha sido herramienta para transmitir el dogma mariano de la Inmaculada Concepción pues luce la luna bajo sus pies. Así como la creencia de María, como reina y señora, coronada, ornamentada de joyas y con su bastón de mando, tal como lo evidencia el inventario de Ujarrás 1776 en el que se enuncian todas las alhajas que poseía la imagen en ese momento (Jerez, 2018, p. 166). 
Imagen 3. Vestido de la Virgen de Ujarrás. Luce el escudo de Costa Rica con cinco estrellas, previo a la reforma establecida en el decreto ejecutivo del presidente Francisco Orlich en 1964. Recuperado recientemente, luego de su desaparición en la década de 1980.

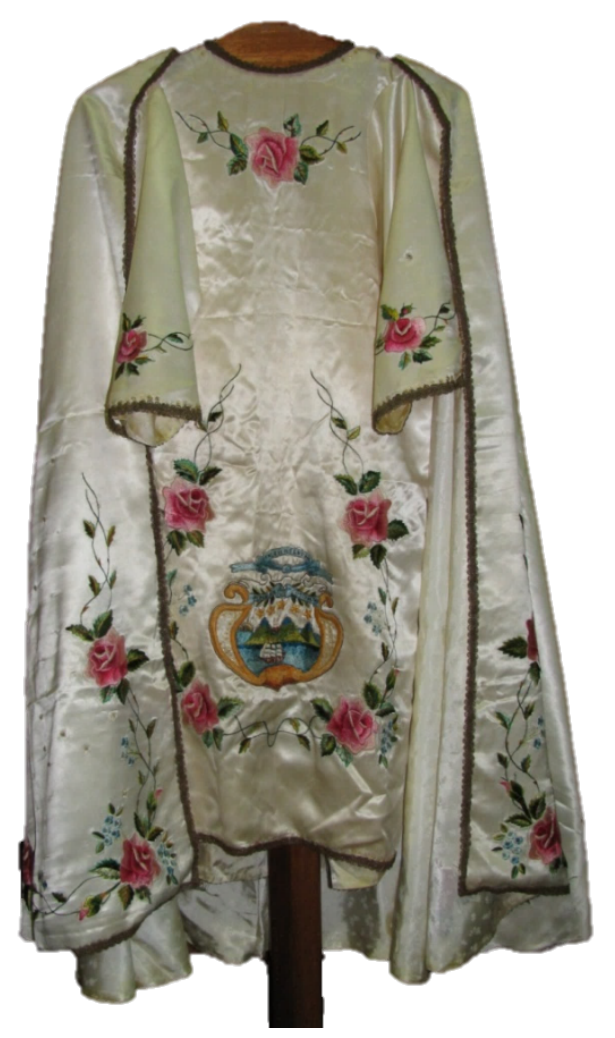

Foto: Luis Carlos Bonilla Soto.

La imagen es vestida por lo general con vestido blanco o rojo, sobre sus espaldas se le coloca un manto azul, por lo que asume elementos de color propios de la iconografía de la Inmaculada Concepción (ver Imagen 3). Sin embargo, dentro del inventario de treinta y nueve vestidos existentes al 17 de junio de 2009, se cuentan lienzos con distintos tonos de rosa, amarillo, naranja, verde y morado. (Inventario de objetos destinados al Culto de la Parroquia de Paraíso realizado por la Asociación Cultural Ujarrás-ACUJA, 2009).

Toda esta dinámica de incorporación de bienes anejos a la imagen demuestra un constante movimiento, que alimenta el culto y provoca una reinvención de la apariencia y la representación de esta advocación a partir del sentir de la feligresía, que ha decantado a su vez, en la reinterpretación de su figura por mano de distintos artistas costarricenses. 


\section{Obras del taller de Manuel Zúñiga}

"El ya famoso artista don Manuel Zúñiga, tiene a cargo la ejecución de estos retablos" (Mensajero del Clero, abril de 1939, p. 2338), es lo que se puede leer en la nota informativa sobre los detalles del altar confeccionado en madera, por los hermanos Elizondo en Cartago, a partir de uno de los diseños encargados a los talleres de Ferdinand Stuflesser en el Tirol.

De manos de dicho artista imaginero salieron, al menos, seis representaciones de la advocación en cuestión, que por una parte han venido a enriquecer el entorno inmediato donde se venera la imagen, es decir su altar mayor y, por otra, a asentar su culto fuera del cantón de Paraíso. Tal es el caso de la réplica muy cercana a la imagen primigenia ${ }^{3}$, venerada en la iglesia parroquial de Barrio Córdoba en San José (ver Imagen 4), y la imagen que se veneró en la iglesia patrimonial de San Rafael Arcángel en Copey de Dota (ver Imagen 5), la cual quedó destruida tras un voraz incendio.

Imagen 4. Réplica de Nuestra Señora para la iglesia de Barrio Córdoba en San José. Obra de Manuel María Zúñiga Rodríguez.

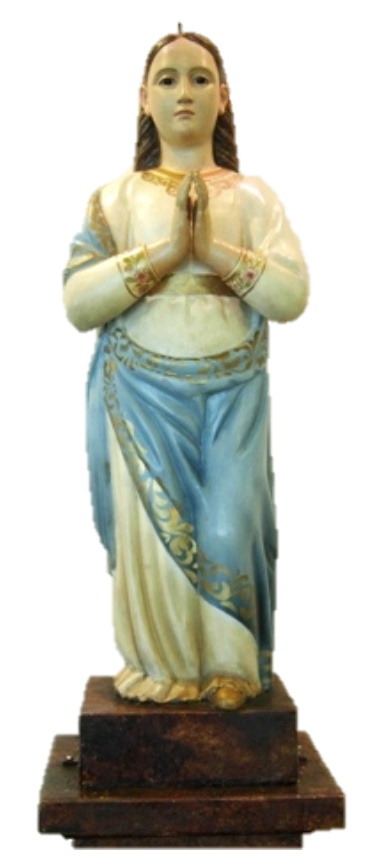

Foto: Luis Carlos Bonilla Soto.

${ }^{3}$ Otra replica notable es la que realizó el escultor cartaginés José Calvo Garita, confeccionada en fibra de vidrio. La misma fue hecha para llevarla a la Basílica de Nuestra Señora de Luján en Argentina en el año 2007, donde se halla expuesta junto a otras advocaciones marianas de todo el mundo. 
Imagen 5. Imagen de la Virgen de Ujarrás destruida junto con la iglesia de Copey de Dota el 6 de agosto de 2017.

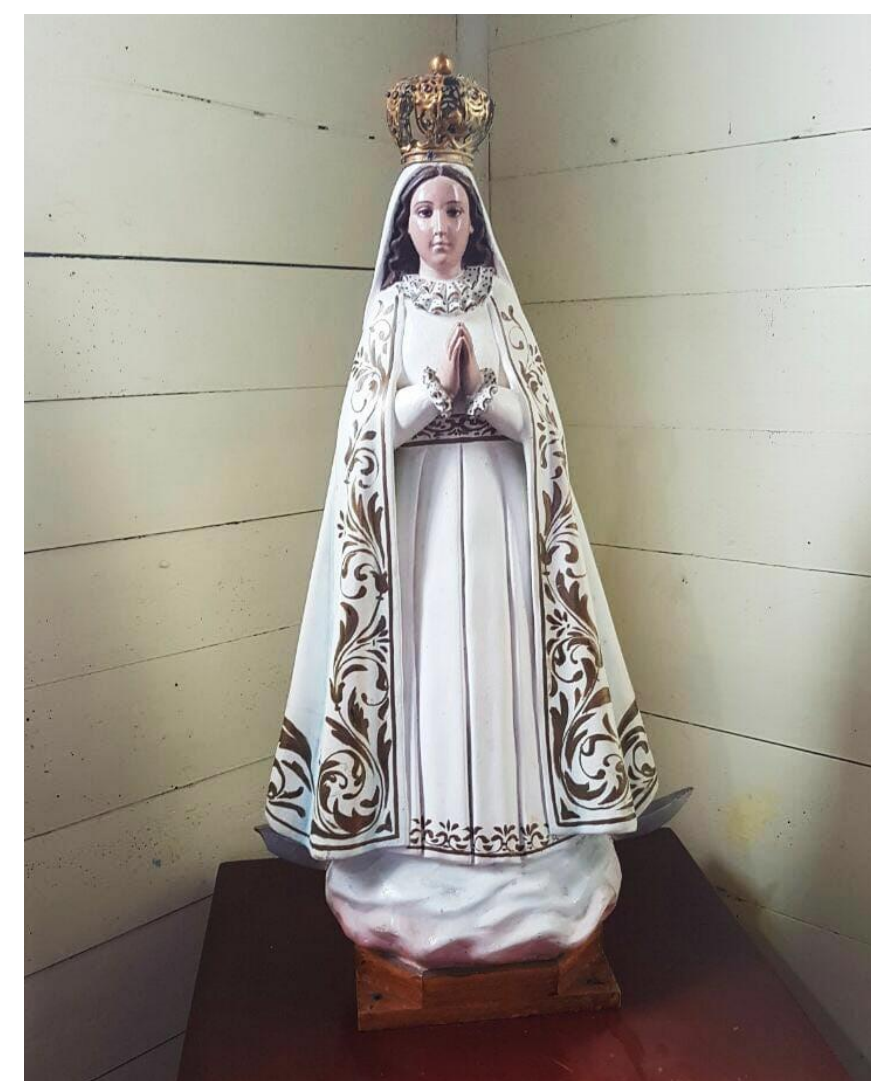

Foto: cortesía de Guiselle Marín Campos.

Los cuatro retablos tallados en madera de los que habla el Mensajero del Clero, fueron hechos con la técnica escultórica de bajo relieve, en los cuales se narra visualmente la historia de la Virgen de Ujarrás asociada a la incursión de los frailes franciscanos, en el Valle que le otorga su nombre (ver Imagen 6). 
En las obras de arte situadas en las iglesias costarricenses no es frecuente encontrar referencias a la geografía, tradiciones culturales, flora y fauna existentes en el país ${ }^{4}$. Aspecto que Zúñiga logró explorar y presentar en los cuatro retablos.

En ellos tuvo clara libertad artística ${ }^{5}$, pues incorpora una serie de elementos propios del paisaje regional donde se veneró la Virgen hasta 1832.

Imagen 6. Retablo del hallazgo. Obra de Manuel María Zúñiga R.

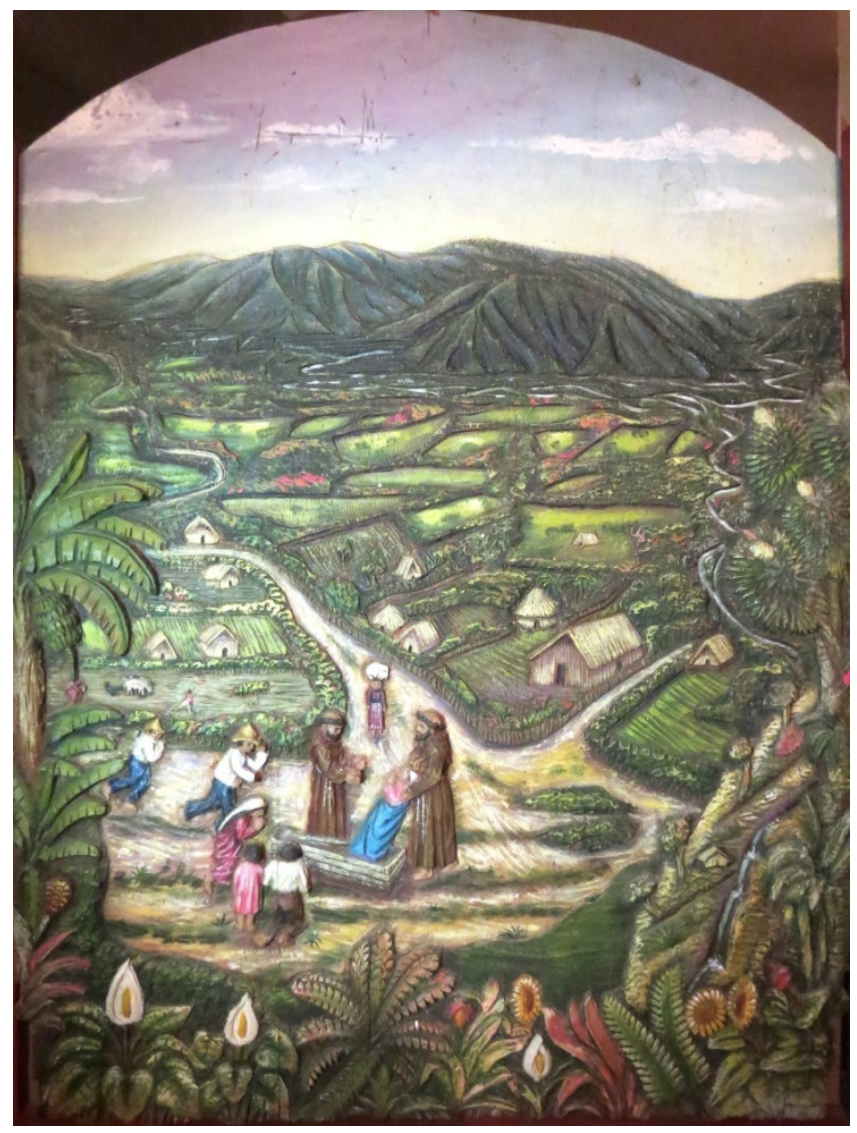

Foto: Luis Carlos Bonilla Soto.

4 Entre los pocos ejemplos están algunos vitrales, en los que se halla la representación de la carreta típica junto a San Isidro (Tabarcia de Mora y San Isidro de Heredia) o los que tienen por tema a Ntra. Sra. de los Ángeles.

5 Esto no sucede con los siete ángeles y el crucifijo que también ornamentan el conjunto del altar. 
Tabla 1. Referencias visuales representadas en los cuatro retablos de Zúñiga, Altar Mayor, Paraíso.

\begin{tabular}{|c|c|c|c|c|c|}
\hline Tema & Personajes & $\begin{array}{l}\text { Referencias } \\
\text { geográficas }\end{array}$ & $\begin{array}{c}\text { Referencias } \\
\text { culturales }\end{array}$ & $\begin{array}{c}\text { Referencias } \\
\text { Vegetales }\end{array}$ & $\begin{array}{c}\text { Referencias } \\
\text { animales }\end{array}$ \\
\hline El hallazgo & $\begin{array}{l}\text { - Virgen en } \\
\text { una caja } \\
\text { - Dos } \\
\text { franciscanos } \\
\text {-Pobladores } \\
\text { venerando }\end{array}$ & $\begin{array}{l}\text { - Montañas de la } \\
\text { Cordillera de } \\
\text { Talamanca } \\
\text { - Cuenca del } \\
\text { Reventazón } \\
\text { - Catarata del } \\
\text { Salto de la } \\
\text { Novia }\end{array}$ & $\begin{array}{l}\text { - Campos } \\
\text { agrícolas } \\
\text {-Arado de la } \\
\text { tierra } \\
\text { - Boyeo } \\
\text { - Viviendas } \\
\text { pajizas } \\
\text { - Casas cónicas }\end{array}$ & $\begin{array}{l}\text { - Bosques en } \\
\text { las montañas } \\
\text { - Vástagos con } \\
\text { plátanos } \\
\text { - Itabos } \\
\text { - Helechos } \\
\text { - Flores } \\
\text { tropicales }\end{array}$ & - Bueyes \\
\hline $\begin{array}{l}\text { Vida } \\
\text { cotidiana del } \\
\text { Valle }\end{array}$ & $\begin{array}{l}\text { - Virgen en } \\
\text { andas } \\
\text { - Personas en } \\
\text { procesión }\end{array}$ & $\begin{array}{l}\text { - Montañas de la } \\
\text { Cordillera de } \\
\text { Talamanca } \\
\text { - Cuenca del } \\
\text { Reventazón }\end{array}$ & $\begin{array}{l}\text { - iglesia (hoy } \\
\text { Ruinas) } \\
\text {-Caserío } \\
\text { - Procesión } \\
\text { - Cestería } \\
\text { - Cerámica } \\
\text { precolombina } \\
\text { - Agricultura }\end{array}$ & $\begin{array}{l}\text { - Árboles } \\
\text { florecidos } \\
\text {-Vástagos con } \\
\text { plátanos } \\
\text {-Piña } \\
\text {-Ayote } \\
\text {-Cacao } \\
\text {-Papa }\end{array}$ & $\begin{array}{l}\text { - Loras } \\
\text { - Monos }\end{array}$ \\
\hline $\begin{array}{l}\text { Milagro de } \\
1666\end{array}$ & $\begin{array}{l}\text { - Virgen } \\
\text { aparecida } \\
\text { - Alonso de } \\
\text { Bonilla }\end{array}$ & $\begin{array}{l}\text { - Montañas de } \\
\text { Quebrada } \\
\text { Honda } \\
\text { - Mar Caribe }\end{array}$ & $\begin{array}{l}\text { - Barcos } \\
\text { piratas } \\
\text {-Armas }\end{array}$ & $\begin{array}{l}\text { - Árboles } \\
\text { florecidos }\end{array}$ & - dos pumas \\
\hline $\begin{array}{l}\text { Procesión } \\
\text { con las } \\
\text { fuerzas de } \\
\text { seguridad }\end{array}$ & $\begin{array}{l}\text { - Virgen en } \\
\text { andas } \\
\text { - Personas en } \\
\text { procesión } \\
\text {-Soldados }\end{array}$ & $\begin{array}{l}\text { - Montañas de la } \\
\text { Cordillera de } \\
\text { Talamanca } \\
\text { - Cuenca del } \\
\text { Reventazón } \\
\text { - Catarata del } \\
\text { Salto de la } \\
\text { Novia }\end{array}$ & $\begin{array}{l}\text { - Campos } \\
\text { agrícolas } \\
\text { - Boyeo y } \\
\text { carreta } \\
\text { - Viviendas de } \\
\text { bahareque } \\
\text { - Casas cónicas } \\
\text { - Ejército y } \\
\text { armas } \\
\text {-iglesia (hoy } \\
\text { Ruinas) } \\
\text { - Procesión }\end{array}$ & $\begin{array}{l}\text { - Palmas } \\
\text { - Árboles } \\
\text { florecidos } \\
\text { - Flores } \\
\text { tropicales }\end{array}$ & - Bueyes \\
\hline
\end{tabular}

Fuente: Elaboración pripia. 
Como se observa en la Tabla 1, la cantidad de referencias a elementos autóctonos de Costa Rica es vasta. Se citan de manera contundente accidentes geográficos y detalles de las vestimentas de los personajes. Prácticas cotidianas como el boyeo, el cultivo de la tierra y la estética domiciliar no escaparon de la composición de cada una de las cuatro piezas talladas. Es esa diversidad de elementos la que les da una riqueza de color y formas que hacen que el observador disponga de abundantes puntos de focalización con respecto a los hechos expuestos, de modo que lo visualmente narrado permite construir un panorama de los rasgos que construyen la identidad de los pobladores de esta región.

\section{Pinturas de Marco Aurelio Aguilar Mata}

Alberto Calderón (2005) en el estudio que realiza con respecto a las doce pinturas $^{6}$ realizadas por el pintor cartaginés Marco Aurelio Aguilar Mata, contextualiza dicho conjunto pictórico dentro de la decoración realizada para dar la bienvenida a la imagen, solemnemente coronada por mandato papal el 27 de abril de 1955, en su regreso desde San José.

Dichas pinturas no fueron pensadas ni elaboradas con un fin perenne, si no como la ornamentación que coronaba cada uno de los doce arcos construidos de manera efímera para el paso del conjunto procesional en la Calle Real de Paraíso.

El material de soporte con el que fueron realizadas -cartón- hace pensar que se realizaron en un soporte de calidad inferior para disminuir costos, de la misma manera en que se realizaban las "instalaciones" artísticas para altares y espacios rituales temporales en el culto católico.

Si bien las obras no fueron hechas para gustar ni para perdurar (Calderón, 2005, p. 28), las mismas se conservaron y colocaron en el espacio y en la mentalidad paraiseña de manera determinante. En el primero, ornamentando las paredes laterales del Santuario de la sagrada imagen en Paraíso y en la segunda, pues es el relato visual del mito originario que explica el milagroso hallazgo narrado por Eladio Prado, el cual cuenta la manera en que un indígena recoge una caja misteriosa que traslada hasta Ujarrás, lugar en el que dicho objeto se vuelve imposible de mover y del cual emerge ante la mirada de los doctrineros franciscanos y los pobladores nativos, la figura de la Virgen María.

\footnotetext{
${ }^{6}$ En dicha publicación se hallan las fotografías de toda la serie de este pintor.
} 
Ambas se conjugan de manera contundente, ya que las pinturas son utilizadas por las personas pobladoras, como recurso didáctico para explicar a las nuevas generaciones este imaginario histórico y religioso.

Desde el punto de vista formal, los doce óleos no deslumbran por su minuciosidad en la composición y diversidad de elementos. Más bien, al estilo del género narrativo de la historieta, se reproducen de modo progresivo los mismos elementos y personajes para lograr contar con mayor facilidad los acontecimientos narrados. A diferencia de los retablos de Zúñiga, Aguilar no se esmera en los detalles. Si se comparan las doce obras (ver Tabla 2), la presencia de ciertos elementos se mantiene con unas pocas variantes, para sostener así el hilo conductor del relato.

Tabla 2. Referencias visuales representadas en las doce pinturas de Marco Aurelio Aguilar Mata, iglesia de Paraíso

\begin{tabular}{|c|c|c|c|c|c|}
\hline Tema & Personajes & $\begin{array}{l}\text { Referencias } \\
\text { geográficas }\end{array}$ & $\begin{array}{c}\text { Referencias } \\
\text { culturales }\end{array}$ & $\begin{array}{c}\text { Referencias } \\
\text { Vegetales }\end{array}$ & $\begin{array}{c}\text { Referencias } \\
\text { animales }\end{array}$ \\
\hline $\begin{array}{l}\text { Objeto } \\
\text { misterioso se } \\
\text { acerca }\end{array}$ & $\begin{array}{l}\text { - Virgen en } \\
\text { una caja } \\
\text { - indígena }\end{array}$ & $\begin{array}{l}\text { - Mar Caribe } \\
\text { - desembocadura } \\
\text { del río Suerre } \\
\text { (Actual Boca } \\
\text { Parismina) }\end{array}$ & $\begin{array}{l}\text { - pesca } \\
\text { - vestimenta } \\
\text { indígena }\end{array}$ & - palmeras & - perro \\
\hline $\begin{array}{l}\text { Indígena } \\
\text { recoge la caja }\end{array}$ & $\begin{array}{l}\text { - Virgen en } \\
\text { una caja } \\
\text { - indígena }\end{array}$ & $\begin{array}{l}\text { - Mar Caribe } \\
\text { - desembocadura } \\
\text { del río Suerre } \\
\text { (Actual Boca } \\
\text { Parismina) }\end{array}$ & $\begin{array}{l}\text { - pesca } \\
\text { - vestimenta } \\
\text { indígena }\end{array}$ & - palmeras & - perro \\
\hline $\begin{array}{l}\text { Indígena } \\
\text { carga caja a } \\
\text { sus espaldas }\end{array}$ & $\begin{array}{l}\text { - Virgen en } \\
\text { una caja } \\
\text { - indígena }\end{array}$ & $\begin{array}{l}\text { - ribera del río } \\
\text { Suerre }\end{array}$ & $\begin{array}{l}\text { - forma de } \\
\text { cargar } \\
\text { - vestimenta } \\
\text { indígena }\end{array}$ & $\begin{array}{l}\text { - árboles } \\
\text { nativos }\end{array}$ & - perro \\
\hline $\begin{array}{l}\text { Indígenas } \\
\text { alrededor de } \\
\text { la caja }\end{array}$ & $\begin{array}{l}\text { - Doce } \\
\text { indígenas } \\
\text { - Virgen en } \\
\text { una caja }\end{array}$ & $\begin{array}{l}\text { - Cerro Santa Lucía } \\
\text { (cc Picacho) } \\
\text { - Quebrada de la } \\
\text { naciente del cerro } \\
\text { Santa Lucía }\end{array}$ & $\begin{array}{l}\text { - vestimenta } \\
\text { indígena. } \\
\text {-forma de } \\
\text { cargar al bebé }\end{array}$ & $\begin{array}{l}\text {-árboles } \\
\text { nativos }\end{array}$ & - perro \\
\hline $\begin{array}{l}\text { Aviso a los } \\
\text { franciscanos }\end{array}$ & $\begin{array}{l}\text { - indígena } \\
\text { - fraile }\end{array}$ & $\begin{array}{l}\text { - Sin referencia } \\
\text { (posiblemente } \\
\text { Cartago) (¿?) }\end{array}$ & $\begin{array}{l}\text { - convento } \\
\text { - vestimentas }\end{array}$ & $\begin{array}{l}\text {-árboles } \\
\text { exóticos }\end{array}$ & \\
\hline
\end{tabular}


cont. Tabla 2.

\begin{tabular}{|c|c|c|c|c|c|}
\hline Tema & Personajes & $\begin{array}{l}\text { Referencias } \\
\text { geográficas }\end{array}$ & $\begin{array}{c}\text { Referencias } \\
\text { culturales }\end{array}$ & $\begin{array}{c}\text { Referencias } \\
\text { Vegetales }\end{array}$ & $\begin{array}{c}\text { Referencias } \\
\text { animales }\end{array}$ \\
\hline $\begin{array}{l}\text { Descubren la } \\
\text { imagen }\end{array}$ & $\begin{array}{l}\text { - ocho } \\
\text { indígenas } \\
\text { - dos frailes }\end{array}$ & $\begin{array}{l}\text { - Cerro Santa } \\
\text { Lucía (cc } \\
\text { Picacho) } \\
\text { - Quebrada } \\
\text { de la } \\
\text { naciente del } \\
\text { cerro Santa } \\
\text { Lucía. }\end{array}$ & $\begin{array}{l}\text { - gestualidad de } \\
\text { veneración. } \\
\text { - vestimentas }\end{array}$ & $\begin{array}{l}\text {-árboles } \\
\text { nativos }\end{array}$ & - perro \\
\hline $\begin{array}{l}\text { Imposibilidad } \\
\text { de mover la } \\
\text { imagen }\end{array}$ & $\begin{array}{l}\text { - cinco } \\
\text { indígenas } \\
\text { - dos frailes }\end{array}$ & $\begin{array}{l}\text { - Cerro Santa } \\
\text { Lucía (cc } \\
\text { Picacho) } \\
\text { - Quebrada } \\
\text { de la } \\
\text { naciente del } \\
\text { cerro Santa } \\
\text { Lucía }\end{array}$ & $\begin{array}{l}\text { - gestualidad de } \\
\text { veneración. } \\
\text { - vestimentas }\end{array}$ & $\begin{array}{l}\text {-árboles } \\
\text { nativos }\end{array}$ & - perro \\
\hline $\begin{array}{l}\text { Levantamiento } \\
\text { de rancho } \\
\text { pajizo }\end{array}$ & $\begin{array}{l}\text { - trece } \\
\text { indígenas } \\
\text { - cuatro frailes }\end{array}$ & $\begin{array}{l}\text { - Valle de } \\
\text { Ujarrás }\end{array}$ & $\begin{array}{l}\text { - tala de árboles } \\
\text {-procesión }\end{array}$ & $\begin{array}{l}\text {-árboles } \\
\text { nativos }\end{array}$ & \\
\hline $\begin{array}{l}\text { Milagro del } \\
\text { Rescate }\end{array}$ & $\begin{array}{l}\text { - Alonso de } \\
\text { Bonilla } \\
\text { - Virgen con } \\
\text { multitud de } \\
\text { ángeles } \\
\text { - Multitud de } \\
\text { piratas }\end{array}$ & $\begin{array}{l}\text { - Quebrada } \\
\text { Honda de } \\
\text { Juan Viñas } \\
(¿ ?)\end{array}$ & $\begin{array}{l}\text { - armas } \\
\text { - vestimentas }\end{array}$ & $\begin{array}{l}\text { - Hierbas y } \\
\text { bosques }\end{array}$ & \\
\hline $\begin{array}{l}\text { Construcción } \\
\text { de la iglesia } \\
\text { de cal y canto }\end{array}$ & $\begin{array}{l}\text { - fraile } \\
\text { - dos jóvenes }\end{array}$ & - Ujarrás & $\begin{array}{l}\text { - arquitectura } \\
\text { - } \\
\text { adoctrinamiento }\end{array}$ & $\begin{array}{l}\text {-árboles } \\
\text { nativos }\end{array}$ & \\
\hline $\begin{array}{l}\text { Traslado de } \\
1832\end{array}$ & $\begin{array}{l}\text { - Virgen } \\
\text { - Multitud de } \\
\text { ujarreceños }\end{array}$ & $\begin{array}{l}\text { - Salto de la } \\
\text { Novia }\end{array}$ & $\begin{array}{l}\text { - instrumentos } \\
\text { de labranza } \\
\text { - carreta y } \\
\text { boyeo } \\
\text { - objetos } \\
\text { domésticos } \\
\text { - procesión }\end{array}$ & - montaña & $\begin{array}{l}\text { - cerdo } \\
\text { - perro } \\
\text { - bueyes }\end{array}$ \\
\hline $\begin{array}{l}\text { Coronación } \\
\text { Pontificia en } \\
1955\end{array}$ & $\begin{array}{l}\text { Virgen } \\
\text { coronada, } \\
\text { (vestimenta } \\
\text { emula la } \\
\text { encargada para } \\
\text { el } \\
\text { acontecimiento }^{7} \text { ) }\end{array}$ & & $\begin{array}{l}\text { - Vestidos y } \\
\text { ornamentación } \\
\text { de reina }\end{array}$ & & \\
\hline
\end{tabular}

Fuente: Elaboración propia.

${ }^{7}$ Eladio Prado (1989) describe que la santa imagen lucía su precioso y lucido vestido nuevo que el señor Pbro. Vicente Salazar había encargado personalmente a unas religiosas de Madrid, en España, expertas en labores de mano. El vestido fue robado de la parroquia de Paraíso en la década de 1980. 
Lo que destaca sobremanera del conjunto es la capacidad del pintor para lograr el cometido en un tiempo tan reducido, plasmarlos en un formato de considerables dimensiones, trasladar la leyenda del hallazgo de la pluma de Eladio Prado a su pincel y lograr construir en el imaginario colectivo regional una idea común acerca de la llegada de la imagen patronal y sus dotes milagrosos.

\section{Vitral y murales}

El culto a la Virgen se fomentó luego de que en 1920, Eladio Prado, publicara la primera edición del libro "Nuestra Señora de Ujarrás" y Monseñor Víctor Manuel Arrieta publicara distintas notas sobre ella en el períodico el Eco Católico. Con la investigación de Prado se elaboró una novena y con el impuso devocional de Arrieta, se empezó a conocer la devoción en otras partes del país.

Lo anterior decantó en el trámite para la coronación ante el Vaticano, que fue elevada por el tercer arzobispo de San José, Rubén Odio Herrera, al cardenal Federico Tedeschini, con fecha del 12 de septiembre de 1953:

\footnotetext{
"Por todos esos motivos, (...) [se] suplica a Vuestra Eminencia Reverendísima y al Venerable Cabildo de la Patriarcal Basílica Vaticana, se dignen otorgar a la imagen de Nuestra Señora de la Limpia Concepción del Rescate de Ujarrás, el privilegio de ser coronada solemnemente con corona de oro, para que el honor de la madre redunde una vez más en gloria del hijo, Jesucristo Nuestro Señor." (Carta citada por Parroquia de Paraíso, 2005).
}

La coronación se llevó a cabo el miércoles 27 de abril de 1955 por el cardenal Carlos María de la Torre, procedente de Quito, Ecuador, esto en el contexto del II Congreso Eucarístico Nacional del 22 al 29 de abril de ese año. En dicha semana la imagen fue recibida en varias parroquias josefinas: San Pedro de Montes de Oca (viernes 22 de abril), La Soledad (domingo 24 de abril), La Dolorosa (lunes 25 de abril) allí recibió homenaje de la Colonia Española, El Carmen (martes 26 de abril) y la Catedral Metropolitana.

La coronación pontificia tuvo gran incidencia en las comunidades parroquiales josefinas. Evidencia de ello es una de las dieciséis vidrieras encargadas a la empresa Tiroler Glasmarelei para la iglesia de Santa Teresita (ver Imagen 7). En este vitral destacan las banderas del Estado Vaticano y el Estado de Costa Rica en forma de lazos al pie de la Virgen. Luce ella con los colores blanco y azul propios de la Inmaculada Concepción y coronada con la pieza de oro confeccionada por los orfebres del Valle (Bonilla, 2019, p. 84). 
Imagen 7. Vitral elaborado en Austria por la empresa Tiroler Glasmarelei para la iglesia de santa Teresita en B Aranjuez, San José. 1958.

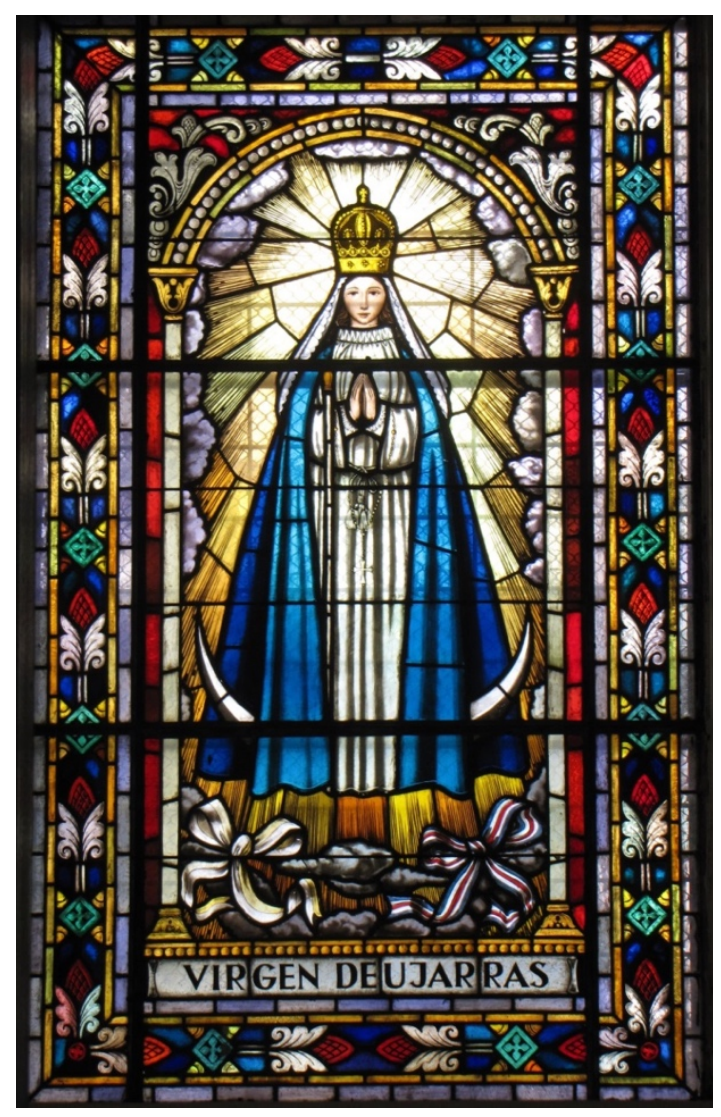

Foto: Luis Carlos Bonilla Soto.

Asimismo, se promulgó el 09 de abril de 1973 la Ley No. 3112 que la designó como Capitana General y Patrona de la Guardia Civil y de los Cuerpos de Seguridad de Costa Rica. Título otorgado en función del relato asociado a la expulsión de los piratas Mansfield y Morgan del 16 de abril de 1666 y que es el tema del mural en mosaico realizado por José Miguel Páez para la iglesia de Barrio Córdoba en el 2004 (ver Imagen 8). 
Revista Herencia, Vol. 33 (2), julio-diciembre, 2020.

Imagen 8. Mural del Milagro de 1666. Obra de José Miguel Páez (2004) en los exteriores de la iglesia parroquial en Barrio Córdoba

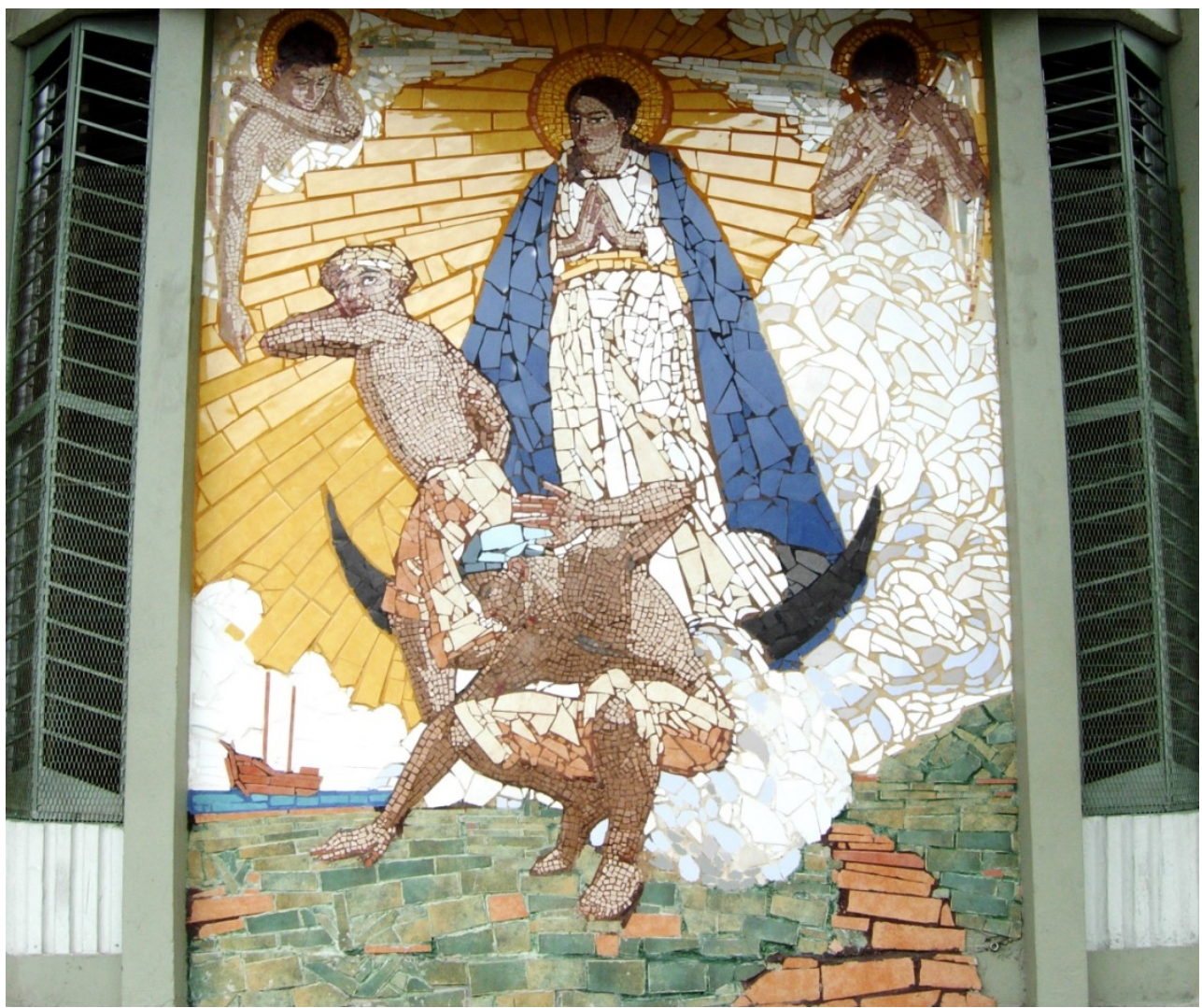

Foto: Luis Carlos Bonilla Soto. 
Tabla 3. Lenguaje iconográfico del vitral y los murales de la Virgen de Ujarrás, Costa Rica

\begin{tabular}{|c|c|c|c|c|c|}
\hline Obra & Ubicación & Autor & $\begin{array}{c}\text { Indumentaria } \\
\text { de la Virgen de } \\
\text { Ujarrás }\end{array}$ & $\begin{array}{c}\text { Referencias } \\
\text { históricas }\end{array}$ & $\begin{array}{c}\text { Referencias } \\
\text { Naturales }\end{array}$ \\
\hline $\begin{array}{l}\text { Vitral de } \\
\text { Nuestra } \\
\text { Señora de } \\
\text { Ujarrás }\end{array}$ & $\begin{array}{l}\text { - iglesia de } \\
\text { santa } \\
\text { Teresita, San } \\
\text { José }\end{array}$ & $\begin{array}{l}\text { - Tiroler } \\
\text { Glasmarelei }\end{array}$ & $\begin{array}{l}\text { - Vestido y velo } \\
\text { blancos } \\
\text { - Manto azul. } \\
\text { - Luna bajo sus } \\
\text { pies. } \\
\text { - Corona, cetro y } \\
\text { rosario }\end{array}$ & $\begin{array}{l}\text { - Banderas de } \\
\text { Costa Rica y el } \\
\text { Estado Vaticano. } \\
\text { - Coronación } \\
\text { pontificia de } 1955\end{array}$ & - Nubes y luz \\
\hline $\begin{array}{l}\text { Mural del } \\
\text { Traslado }\end{array}$ & $\begin{array}{l}\text { - Salón del } \\
\text { Concejo } \\
\text { Municipal de } \\
\text { Paraíso }\end{array}$ & - Luis Quirós & $\begin{array}{l}\text { - Vestida toda de } \\
\text { blanco. } \\
\text { - llevada en } \\
\text { andas encabeza } \\
\text { la caminata. }\end{array}$ & $\begin{array}{l}\text { - Traslado de la } \\
\text { población del } 13 \\
\text { de julio de } 1832 .\end{array}$ & $\begin{array}{l}\text { - Montañas } \\
\text { - Catarata del } \\
\text { Salto de la } \\
\text { Novia }\end{array}$ \\
\hline $\begin{array}{l}\text { Mural } \\
\text { alegórico } \\
\text { de Paraíso }\end{array}$ & $\begin{array}{l}\text { - Salón del } \\
\text { Concejo } \\
\text { Municipal de } \\
\text { Paraíso }\end{array}$ & - Luis Quirós & $\begin{array}{l}\text { - Vestida toda de } \\
\text { blanco. } \\
\text { - Ubicada en su } \\
\text { altar }\end{array}$ & $\begin{array}{l}\text { - Banderas de } \\
\text { Costa Rica y el } \\
\text { Estado Vaticano. } \\
\text { - Representación } \\
\text { de personajes } \\
\text { ilustres de Ujarrás } \\
\text { y paraíso }\end{array}$ & $\begin{array}{l}\text { - Sol y } \\
\text { montañas }\end{array}$ \\
\hline $\begin{array}{l}\text { Mural del } \\
\text { Milagro de } \\
\text { Quebrada } \\
\text { Honda }\end{array}$ & $\begin{array}{l}\text { - iglesia de } \\
\text { Barrio } \\
\text { Córdoba, } \\
\text { San José }\end{array}$ & $\begin{array}{l}\text { - José } \\
\text { Miguel Páez }\end{array}$ & $\begin{array}{l}\text { - Vestido y velo } \\
\text { blancos } \\
\text { - Manto azul. } \\
\text { - Luna bajo sus } \\
\text { pies. } \\
\text { - Con aureola. } \\
\text { - Rodeada de } \\
\text { ángeles, uno de } \\
\text { ellos le sostiene } \\
\text { el cetro. }\end{array}$ & $\begin{array}{l}\text { - Expulsión de los } \\
\text { piratas Mansfield y } \\
\text { Morgan en } \\
\text { Quebrada Honda } \\
\text { de Juan Viñas. }\end{array}$ & $\begin{array}{l}\text { - Nubes, luz, } \\
\text { mar. }\end{array}$ \\
\hline $\begin{array}{l}\text { Mural del } \\
\text { Traslado }\end{array}$ & $\begin{array}{l}\text { - Biblioteca } \\
\text { Municipal de } \\
\text { Paraíso }\end{array}$ & $\begin{array}{l}\text { - Randall } \\
\text { Picado } \\
\text { Morera }\end{array}$ & $\begin{array}{l}\text { - Vestida toda de } \\
\text { blanco. } \\
\text { - llevada en } \\
\text { andas encabeza } \\
\text { la caminata. }\end{array}$ & $\begin{array}{l}\text { - Traslado de la } \\
\text { población del } 13 \\
\text { de julio de } 1832 .\end{array}$ & - Montañas \\
\hline
\end{tabular}

Fuente: Elaboración propia. 
Otros espacios públicos donde figuran murales en los que se retrata la advocación mariana en cuestión son los dos ubicados en el salón de sesiones de la Municipalidad de Paraíso (ver Imagen 9) y en la Biblioteca Pública del cantón, los primeros ejecutados por el artista Luis Quirós y el último por Randall Picado Morera. Lo que evidencia el peso de la Virgen en la identidad regional más allá de los espacios religiosos.

Imagen 9. Detalle del mural del Traslado de Ujarrás a Paraíso. Obra de Luis Fernando Quirós Valverde. Salón de sesiones de la Municipalidad de Paraíso.

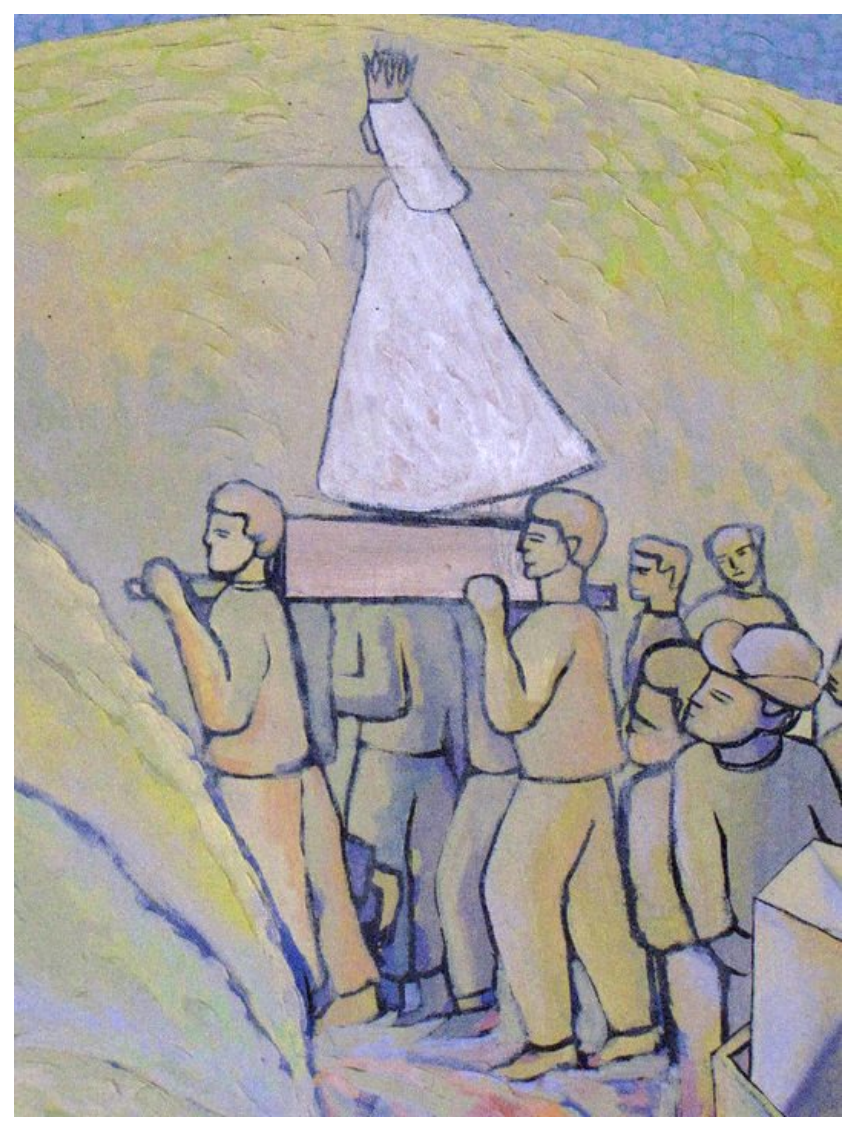

Foto: Luis Carlos Bonilla Soto. 


\section{Ecos en las artistas paraiseñas}

La figura de la Virgen de Ujarrás se halla presente de distintas formas en el imaginario de los pobladores del actual pueblo de Paraíso. De modo que distintas artistas del cantón han plasmado en sus obras la imagen de la patrona del pueblo.

Una de las artistas de mayor importancia fue Margarita Quesada Schmidt, quien desde técnicas disruptivas en la acuarela, plasmó su cotidianidad inmediata mediante estampas de personajes, paisajes y situaciones propias de este poblado. De manera que las procesiones y los rincones sagrados de las iglesias del Valle no escaparon de su óptica para construir su narración pictórica, tal es el caso de la obra en la que se manifiesta una de las tradiciones más arraigada entre las gentes de Paraíso (ver Imagen 10), la cual consiste en llevar la sagrada imagen hacia distintos lugares mientras se reza y se le erigen altares con distintas formas, temáticas y colores.

Imagen 10. Virgen de Ujarrás. Obra de Margarita Quesada Schmidt, s.f.

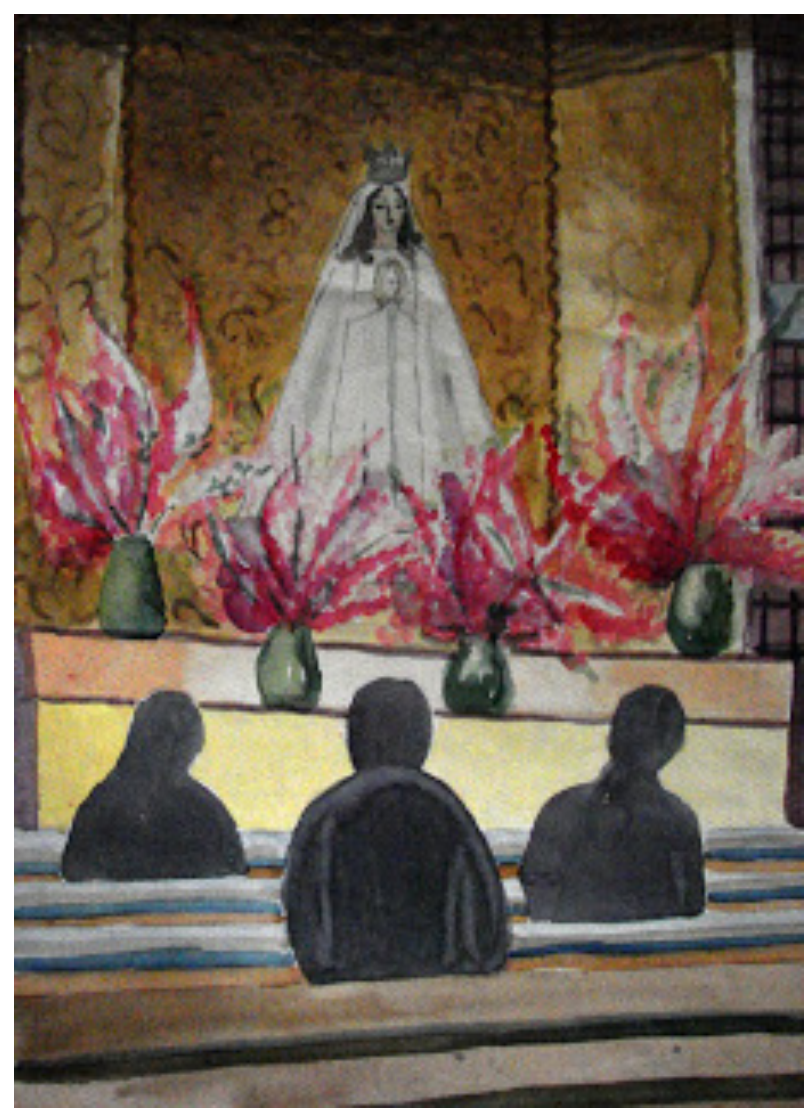

Foto: Luis Quirós Valverde. 
Esta situación que se corrobora hasta la actualidad en la novena preparatoria a la fiesta de la Candelaria el 2 de febrero, en la cual se peregrina entre cantos y oraciones hacia distintos barrios de la comunidad en el contexto de la aurora, así como en la Romería anual que se realiza con la imagen en el mes de abril, la cual se dirige hasta las antiguas ruinas se la iglesia de Ujarrás en horas de la mañana y que regresa nuevamente a su santuario en Paraíso al anochecer. Tradición vinculada directamente al traslado de la población de Ujarrás a Paraíso en 1832, como lo constata Benavides (2002).

Otros artistas paraiseños de distintas generaciones posteriores a Margarita Quesada, muchos de ellos cercanos a su trabajo, como Luis Fernando Quirós Valverde, Matilde Quesada Coghi, Myriam Quirós Quesada, Giacomo Coghi Morales (ver Imagen 11), Juan Ramón Rojas Quesada, Zoleila Solano Ramírez, Ricardo Ávila Baltodano, Roberto Mata Serrano y Fabio Morales Rojas, tienen entre sus temas de realización artística la figura de esta advocación mariana.

Imagen 11. Traslado del pueblo de Ujarrás con la Virgen. Obra de Giacomo Coghi. 2007

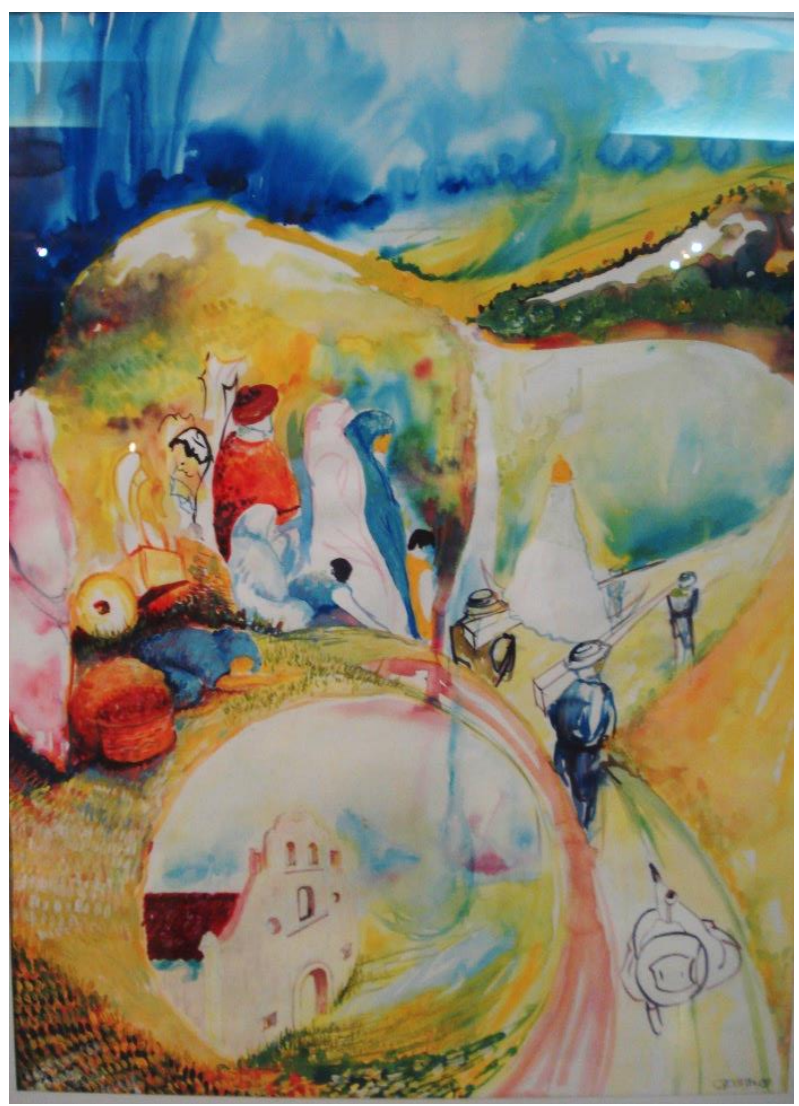

Foto: Luis Carlos Bonilla Soto. 
En los años 2005 y 2007, en el Museo Histórico Religioso Nuestra Señora de Ujarrás, se realizaron dos certámenes de pintura, en los cuales se tuvieron como temas la Virgen de Ujarrás y el traslado poblacional. En ambos certámenes el jurado estuvo compuesto por importantes figuras del ámbito artístico costarricense, a saber, la curadora de artes visuales lleana Alvarado Venegas y los artistas Fello García y Luis Chacón. Dichos certámenes resultaron en 41 pinturas realizadas en distintas técnicas, en las que se vislumbra como elemento central esta imagen mariana. En el caso de las obras concursantes en el 2005, estas la retratan en muchos casos con el "vestido de gracia", es decir, el pintado en la escultura de bulto redondo, con el diseño de la policromía recuperada por la restauradora Mercedes Fontana en la intervención realizada en el 2004. Como se observa en la obra ganadora del primer premio, realizada por Karla Brenes Segura con el nombre "Nuestra Señora de los Valles" (ver Imagen 12).

Imagen 12. Nuestra Señora de los Valles. Obra de Karla Brenes. 2005.

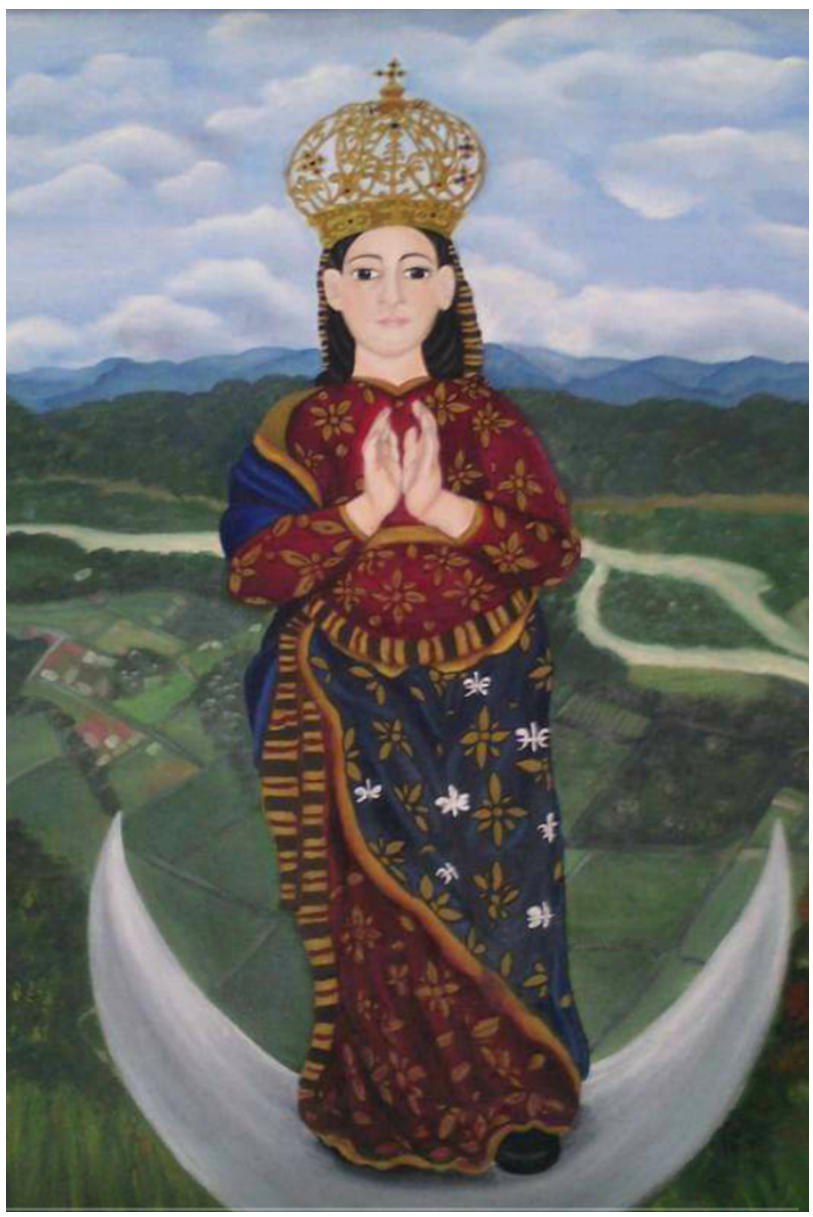

Fotografía cortesía de la artista. 
De modo que muchos hogares paraiseños han sido dotados de obras plásticas con la temática de la Virgen Ujarraceña, algunos a manera de estampa devocional y otros como referente de su identidad local.

\section{Conclusiones}

El culto a la Virgen "Chapetona" surgido, a partir de la escultura de bulto redondo tallada en madera policromada, y asentado originalmente en el valle de Ujarrás, es un culto claramente delimitado a un ámbito regional. El cual forma parte indiscutible de la idiosincrasia de la población de Paraíso.

De dicha advocación se han realizado obras artísticas en soportes de diversa índole, tales como madera, escayola, fibra de vidrio y vitral que retratan los imaginarios, tanto dogmáticos como culturales, en torno la Virgen María nombrada con el título de este fértil valle, situado al este de la ciudad de Cartago.

Las obras plásticas dispuestas en iglesias, altares domésticos y espacios públicos, han posibilitado asentar los imaginarios con respeto al discurso católico sobre la figura de María de Nazaret que se han trasladado, vía inculturación, a las leyendas y mitos originarios que los pobladores, tanto de Ujarrás como de Paraíso, han ido construyendo, gracias en gran parte a los escritos de Eladio Prado y las narraciones orales de las generaciones mayores. De modo que la devoción que gira alrededor de esta advocación autóctona, sigue vigente y potencia la producción de nuevas obras plásticas.

\section{BIBIOGRAFÍA}

\section{Libros y revistas}

(Enero 29 de 1939). Preciosa imagen de la Virgen María llamada la limpia Concepción del Rescate de Ujarrás. Eco Católico. XVI (5).

(Abril de 1939). Altar Mayor de la Iglesia Parroquial de Paraíso. Mensajero del Clero. XLIX (4). 
Asociación Cultural Ujarrás. (2014). El altar de la Virgen de Ujarrás. Paraíso, Cartago.

Benavides, M. (2002). De Ujarrás a Paraíso: Análisis del traslado de una población 1821-1850. San José: Centro de Investigación y Conservación del Patrimonio Cultural. MCJD.

Benavides, M. (2005). La Romería a Ujarrás. Reducto de la identidad cultural de Paraíso. San José: Ediciones Santa María.

Bonilla, L. C. (julio-diciembre, 2019). Herencia en metal: obras de arte sacro de los orfebres del Valle. Herencia 32 (2), pp. 77.96.

Calderón, A. (2005). Las pinturas de Nuestra Señora. Cartago, Costa Rica.

Gutiérrez, F.. (2004, septiembre 13) Un retoque para la macha. La Nación. Disponible en: http://wvw.nacion.com/viva/2004/septiembre/13/portada0.html

Jerez, V. (2018). La devoción a Nuestra Señora de la Pura y Limpia Concepción de la Candelaria del Rescate de Ujarrás: un estudio de la mentalidad religiosa en Costa Rica: 1593-1852. Tesis para optar por el grado de Maestría Académica en Historia por la Universidad de Costa Rica.

Le Franc R. (2013). Un hecho curioso acerca de la imagen de Nuestra Señora de la Limpia Concepción del Rescate de Ujarrás. Boletín Electrónico Museo Nacional. Vol. 6, No. 2, febrero. Disponible en:

http://www.museocostarica.go.cr/es cr/aportes/la-virgen-de-ujarrs.html?|temid $=120$

Monge, M. J. (2015). No a la Realidad. San José. Fundación Museos Banco Central de Costa Rica.

Páez, J. M. (2004). Un mural para el templo católico de Barrio Córdoba. Tesis para optar por el grado de licenciado en Artes Plásticas por la Universidad de Costa Rica.

Parroquia de Paraíso (Abril, 2005). 50 aniversario. Coronación de la Virgen de Ujarrás: un hito en nuestra historia. 
Prado, E. (1989). Nuestra Señora de Ujarrás. San José: Editorial Costa Rica.

Quirós, S. (s.f.). El desarrollo artístico en Paraíso. Disponible en: https://issuu.com/silviaquiros-calderon/docs/el desarrollo art stico

Sanabria, V. M. (2014). Reseña Histórica de la Iglesia en Costa Rica desde 1502 hasta 1850 (Apuntamientos históricos). San José. EUNED.

Zapparoli, M. (enero-diciembre, 2000). De andas y romerías: La aparición de la Virgen de Ujarrás. Herencia 13 (2), pp 35-48.

Zeledón, E. (1998). El Santoral Costarricense, Fiestas y Tradiciones. San José: Editorial UCR. pp. 53-59.

\section{Documentos inéditos}

Asociación Cultural Ujarrás. (2009). Inventario de objetos destinados al Culto de la Parroquia de Paraíso, Cartago.

\section{Comunicación personal}

Quirós, M. (2019, noviembre del). Entrevista con Myriam Quirós Quesada. Paraíso, Cartago. 